\title{
Legalisasi Dan Pengelolaan Usaha Pada UMKM
}

\author{
Martha Suhardiyah $^{1}$, Ulfa Puspa Wanti Widodo ${ }^{2}$, Yurida Sasmita ${ }^{3}$ \\ ${ }^{1,2}$ Program Studi Akuntansi, Fakultas Ekonomi, Universitas PGRI Adi Buana Surabaya \\ ${ }^{3}$ Mahasiswa Progdi Akuntansi, Fakultas Ekonomi, Universitas PGRI Adi Buana Surabaya \\ E-mail: martha@unipasby.ac.id
}

\begin{abstract}
ABSTRAK
Desa Bakalan Kecamatan Gondang memiliki usaha mikro, kecil, dan menengah (UMKM) berupa oleh-oleh makanan ringan, yaitu kacang sembunyi, keripik usus dan keripik pisang. Untuk produk keripik pisang dalam segi penentuan harga pokok dan pemasaran online sudah berjalan dengan baik tetapi perihal perizinan, pembukuan sederhana, dan packaging atau labeling (3P) belum berjalan dengan maksimal. Maka dari itu, program kerja kami hanya fokus pada 3P produk keripik pisang. Program pengabdian masyarakat ini menggunakan metode kualitatif dengan menggunakan survei dan observasi serta wawancara dalam teknik pengumpulan datanya. Hasil program pengabdian ini berupa pelaksanaan kepengurusan izin Sertifikat Produksi Pangan Industri Rumah Tangga (SPP-IRT), pembukuan sederhana, dan perbaikan packaging pada produk keripik pisang "AQILA". Pentingnya 3P untuk meningkatkan daya saing dan kualitas sangat dibutuhkan oleh UMKM agar bisa bertahan dan terus bersaing ditengah-tengah UMKM yang telah ada dan UMKM baru.
\end{abstract}

Kata kunci : SPP-IRT, pembukuan sederhana, packaging

\begin{abstract}
Bakalan village, Gondang sub-district, has home industries such as snacks for hand gift for example kacang sembunyi, usus chips and banana chips. The price and online marketing for banana crispy are done well but for the license, book keeping, and packaging or labeling (3P) are not running well. Moreover, our program wants to focus on banana crispy home industry to help and socialization those three things. This social program used qualitative method survey, observation, and interview to collect the data. The result of this program are accomplishment the license of banana crispy, book keeping, and renew the packaging of "AQILA" banana crispy. The importance of $3 P$ are to enhance the competitiveness and quality of UMKM to survive and compete with any others UMKM.
\end{abstract}

Keywords : SPP-IRT license, book keeping, packaging

\section{PENDAHULUAN}

Sebagai orang Indonesia tentu aktivitas kita sehari-hari tak lepas dari berbagai layanan dan barang hasil kreasi pelaku Usaha Mikro, Kecil, dan Menengah (UMKM). Kebanyakan dari UMKM berhubungan dengan kuliner, baik makanan ringan seperti keripik/kerupuk maupun makanan basah seperti kue-kuean dan minuman. (Ayodya, 2018). UMKM menjadi salah satu sektor perekonomian yang berperan sangat penting dalam sebuah negara. UMKM memiliki kontribusi yang sangat besar dan krusial bagi perekonomian Indonesia secara makro. 
UMKM bergerak dalam hal perdagangan dimana dalam hal ini menyangkut pada aktivitas atau kegiatan berwirausaha. UMKM merupakan suatu usaha perdagangan yang dikelola oleh perorangan atau juga badan usaha yang dalam hal ini termasuk juga sebagai kriteria usaha dalam lingkup kecil atau juga mikro. Peraturan mengenai UMKM terdapat pada Undang-Undang Nomor 20 Tahun 2008 (Pemerintah Republik Indonesia, 2008).

Berdasarkan laporan Kementerian Koperasi dan Usaha Kecil Menengah Republik Indonesia tahun 2017, UMKM memiliki jumlah unit usaha yang sangat besar yaitu sekitar 99,99\% (62,9 juta unit) dari total keseluruhan pelaku usaha di Indonesia dan terjadi kenaikan unit usaha sebesar 2,02\% dari tahun 2017 sampai 2018. Sektor UMKM juga berkontribusi terhadap Produk Domestik Bruto (PDB) Indonesia tahun 2017 sebesar 60,90\% dengan tingkat perkembangan sebesar 9,64\% dari tahun 2017 sampai 2018 (Kementerian Koperasi dan UKM, 2018). Wakil Ketua Komite Ekonomi dan Industri Nasional (KEIN), Arif Budimanta, mengungkapkan pada tahun 2019 UMKM meningkatkan laju pertumbuhan ekonomi sebesar 7\%, selain itu UMKM juga berkontribusi sebanyak 36,82 \% terhadap PDB Indonesia (CNN Indonesia, 2019). Dari data tersebut, dapat dilihat bahwa sektor UMKM berpotensi besar dalam meningkatkan perekonomian di Indonesia.

Di era digital saat ini, bentuk UMKM tidak terbatas pada toko secara fisik (offline) saja, tetapi para pelaku usaha sudah memasuki ranah pemasaran secara online. Untuk dapat memasarkan produk secara legal, pelaku usaha perlu memiliki sertifikat perijinan tetapi hal tersebut seringkali diabaikan. Salah satu sertifikat perijinan yang dimaksud adalah Sertifikat Produksi Pangan Industri Rumah Tangga (SPP-IRT). Minimnya informasi mengenai SPP-IRT mengakibatkan beberapa pelaku UMKM yang memproduksi makanan belum memiliki ijin edar atas produknya. Hal tersebut secara tidak langsung dapat mempengaruhi daya saing produk UMKM dengan produk hasil industri yang lebih besar.

Unsur kedua yang sering dihiraukan pengusaha kecil adalah pembukuan. Sebagian besar dari mereka justru menghindarinya dengan alasan rumit dan membuang-buang waktu padahal pembukuan dapat dikatakan penting untuk melakukan strategi pemasaran ke depannya. Melalui pembukuan pemilik usaha dapat melihat seberapa besar keuntungan yang didapat pada periode sebelumnya dan pembukuan dapat dijadikan patokan untuk strategi ke depannya. Apabila keuntungan yang didapatkan pada periode sebelumnya besar, mungkin saja pelaku UMKM bisa melanjutkannya. Jika keuntungannya kecil, mungkin mereka harus menggunakan strategi lain yang lebih berfungsi optimal. Pembukuan sangat penting bagi bisnis, terutama bagi para pelaku UMKM yang masih terbatas dalam melakukan penjualan. Dengan membuat pencatatan yang rapi, pelaku UMKM dapat terhindar dari kerugian atau bahkan gulung tikar (Andriawan, 2019).

Unsur ketiga yang sering dihiraukan oleh pengusaha kecil adalah packaging produk atau kemasan. Melalui packaging yang unik dan menarik, konsumen dapat menilai merk dan kualitas produk secara positif. Efek dari penilaian positif tersebut antara lain penjualan produk dapat ditingkatkan dan produk tersebut akan memiliki daya saing yang 
baik terhadap produk kompetitor. Saat ini, banyak konsumen yang lebih memperhatikan informasi yang tertera pada kemasan suatu produk. Sehingga produk dengan packaging yang lebih informatif akan cenderung disukai oleh konsumen jika dibandingkan dengan produk dengan packaging yang kurang informatif. Dampak positif dari packaging yang baik dan informatif tidak selalu dipahami oleh pengusaha kecil sehingga masih banyak produk UMKM yang memiliki packaging kurang menarik dan kurang informatif.

Desa Bakalan merupakan desa yang masyarakatnya bermata pencaharian sebagian besar sebagai petani, pegawai swasta dan sisanya sebagai pengusaha. Diantara usahausaha yang ada di desa Bakalan, tiga diantaranya berupa UMKM yang memproduksi jajanan atau oleh-oleh makanan ringan meliputi kacang sembunyi, keripik usus dan keripik pisang. Usaha kacang sembunyi sudah berdiri sejak 11 tahun yang lalu sedangkan usaha keripik usus berdiri sejak 5 tahun yang lalu. Produksi kacang sembunyi dilakukan setiap hari sedangkan keripik usus hanya 3 hari sekali. UMKM tersebut memiliki pegawai tetap sekitar 25 orang untuk produksi kacang sembunyi sedangkan produksi keripik usus memiliki 5-10 orang pegawai tidak tetap. Pemasaran kedua produk tersebut sudah menggunakan bentuk offline dan online ke sebagian wilayah Indonesia.

Dalam hal perizinan, penentuan harga pokok, pembukuan sederhana, packaging atau labeling, dan pemasaran online dari produk kacang sembunyi dan keripik usus sudah dilakukan dengan baik meskipun belum maksimal. Untuk produk keripik pisang dalam segi penentuan harga pokok dan pemasaran online sudah berjalan dengan baik tetapi perihal perizinan, pembukuan sederhana, packaging atau labeling (3P) belum berjalan dengan maksimal. Maka dari itu program kerja kami hanya fokus pada UMKM keripik pisang dengan cara membantu dan mensosialisasikan 3P yang belum berjalan dengan maksimal.

\section{KAJIAN LITERATUR}

\section{Sertifikat Produksi Pangan Industri Rumah Tangga (SPP-IRT)}

Menurut Badan Pengawas Obat dan Makanan Republik Indonesia (BPOM RI) (2018), sertifikat Produksi Pangan Industri Rumah Tangga (SPP-IRT) adalah jaminan tertulis yang diberikan oleh Bupati/Walikota terhadap Pangan Produksi Industri Rumah Tangga Pangan (IRTP) di wilayah kerjanya yang telah memenuhi persyaratan pemberian SPP-IRT dalam rangka peredaran Pangan Produksi IRTP. Dengan adanya SPP-IRT, pemilik usaha dapat menjual produknya secara legal dan aman serta dapat mencakup pangsa pasar yang lebih luas lagi jika dibandingkan dengan produk yang tidak memiliki SPP-IRT. Hal tersebut dapat mendorong kepercayaan konsumen terhadap produk dan diharapkan dapat meningkatkan penjualan atas produk.

Dalam peraturan BPOM Nomor 22 Tahun 2018 tentang Pedoman Pemberian SPPIRT disebutkan bahwa ada beberapa jenis pangan yang tidak diizinkan untuk memperoleh SPP-IRT, antara lain pangan yang di pasteurisasi, frozen food, pangan diet khusus, pangan keperluan medis khusus, dan pangan dari hewan yang dibekukan (Badan Pengawas Obat dan Makanan, 2018). Pengajuan atas SPP-IRT telah diatur dalam peraturan BPOM tersebut dengan jangka waktu berlaku paling lama 5 (lima) tahun dan pemilik usaha dapat 
memperpanjang izin tersebut paling lambat 6 (enam) bulan sebelum masa berlakunya berakhir.

\section{Pembukuan Sederhana}

Menurut Undang-Undang Nomor 28 Tahun 2007 pasal 1 ayat 29, pembukuan merupakan suatu proses pencatatan yang dilakukan secara teratur untuk mengumpulkan data dan informasi keuangan. Pencatatan keuangan ini meliputi harta, kewajiban, modal, penghasilan, dan biaya, serta jumlah harga perolehan dan penyerahan barang atau jasa. Seluruh data tersebut akan digunakan untuk menyusun laporan keuangan pada periode tersebut (Pemerintah Republik Indonesia, 2007).

Pencatatan pembukuan dapat menjadi suatu permasalahan bagi pelaku UMKM karena kurangnya sosialisasi dan informasi terkait penyusunan pembukuan tersebut. Masih terdapat stigma dalam pelaku UMKM bahwa pembukuan sulit dan rumit untuk dilakukan, sehingga mereka cenderung untuk mengabaikan pencatatan transaksi dalam usahanya. (Desra, 2020). Banyak pelaku UMKM yang jarang membuat pembukuan sederhana karena mereka lebih fokus terhadap produk, dan penjualan atas produk atau jasanya padahal pembukuan merupakan salah satu tugas utama dalam sebuah bisnis. Karena itu, setiap bisnis baik skala besar atau pun kecil perlu membuat pembukuan keuangan meskipun sederhana. Hal ini diperlukan karena pembukuan dapat digunakan sebagai alat untuk mengatur arus kas masuk dan keluar sehingga dapat memperkirakan berapa modal yang harus diputar lagi untuk keberlangsungan usaha. Pembukuan juga mempermudah pencatatan transaksi yang lebih rinci dan pencatatan pelunasan utang piutang yang dimiliki.

\section{Packaging}

Menurut Klimchuk dan Krasovec (2006) packaging atau kemasan merupakan suatu desain kreatif yang dibuat untuk memasarkan suatu produk dimana desain tersebut menggunakan bentuk, struktur, material, warna, dan elemen-elemen desain yang informatif sehingga produk tersebut memiliki ciri khas tersendiri.

Packaging produk menjadi alat yang cukup penting dalam pemasaran karena kemasan yang memiliki kesan baik, memiliki ciri khas tersendiri, dan memuat hal-hal informative terkait dengan produk dapat menarik minat konsumen dan mendorong penjualan (Rangkuti, 2006). Menurut Kotler (1999), packaging memiliki empat fungsi, yaitu:

1. Self service, dimana packaging mampu menjelaskan keseluruhan produk dengan baik

2. Consumer offluence, dimana konsumen bersedia membayar lebih atas packaging yang lebih menarik

3. Company and brand image, dimana informasi perusahaan dan merk tercermin dalam packaging produk

4. Inovational opportunity, dimana packaging yang inovatif dapat menguntungkan konsumen dan produsen 


\section{METODE PELAKSANAAN}

Kegiatan pengabdian masyarakat ini menggunakan langkah-langkah kegiatan sebagai berikut:

1. Survei UMKM di Desa Bakalan.

2. Survei ke Dinas Kesehatan Mojokerto.

3. Sosialisasi pembukuan, SPP-IRT, dan packaging di UMKM keripik pisang.

\section{HASIL DAN PEMBAHASAN}

\section{Sosialisasi SPP-IRT}

Berdasarkan observasi dan wawancara yang telah dilakukan kepada Ibu Masmuah, sebagai pemilik dari UMKM keripik pisang, menunjukkan bahwa usaha kripik pisang "AQILA" di Desa Bakalan belum memiliki izin SPP-IRT. Oleh karena itu, kami melakukan sosialisasi izin PIRT kepada Ibu Masmuah mengenai apa itu izin SPP-IRT, tujuan dan manfaatnya, serta seberapa penting SPP-IRT harus dimiliki oleh sebuah UMKM. Selain itu, kami juga membantu menanyakan persyaratan dan kepengurusan izin SPP-IRT kepada Dinas Kesehatan Kabupaten Mojokerto. Dari kegiatan tersebut, Ibu Masmuah bersedia untuk melakukan kepengurusan izin SPP-IRT pada tahun ini, dengan waktu, tanggal, dan tempat penyuluhan sesuai dengan yang ditentukan oleh Dinas Kesehatan Kabupaten Mojokerto. Hasil dokumentasi sosialisasi SPP-IRT dengan Ibu Masmuah dan wawancara dengan Dinas Kesehatan Kabupaten Mojokerto dapat dilihat pada gambar dibawah ini:

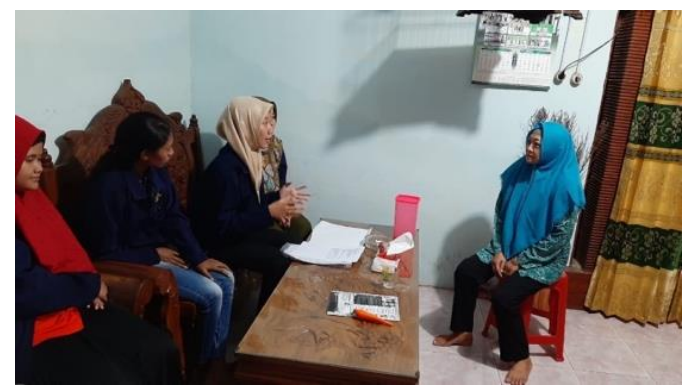

\section{Gambar 1. Sosialisasi SPP-IRT dengan Ibu Masmuah}

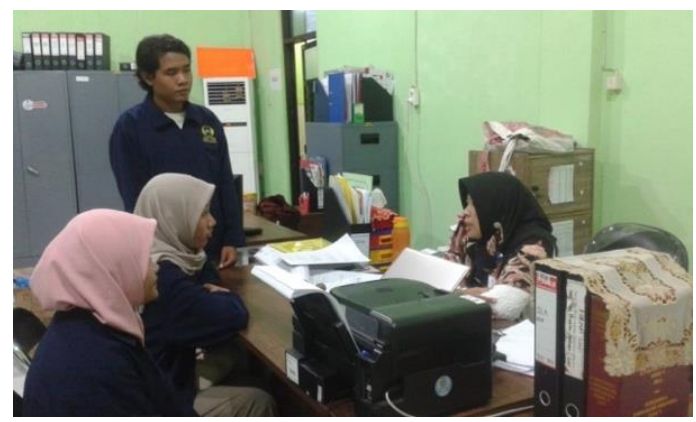

Gambar 2. Wawancara dengan Dinas Kesehatan Kabupaten Mojokerto 


\section{Sosialisasi Pembukuan Sederhana}

Berdasarkan observasi dan wawancara yang telah kami lakukan kepada Ibu Masmuah, sebagai pemilik dari UMKM keripik pisang, menunjukkan bahwa usaha keripik pisang “AQILA” di Desa Bakalan belum melakukan pembukuan sederhana pada usahanya. Oleh karena itu, kami melakukan sosialisasi mengenai apa itu pembukuan sederhana, tujuan dan manfaatnya, serta seberapa penting pembukuan sederhana harus dilakukan oleh pemilik usaha UMKM. Dari sosialisasi yang telah kami lakukan mengenai pembukuan sederhana, beliau sangat antusias dan semangat dalam belajar bagaimana membuat sebuah pembukuan sederhana untuk usahanya.

Setelah Ibu Masmuah paham mengenai tata cara pembukuan sederhana yang telah kami ajarkan, beliau berkomitmen untuk hari-hari selanjutnya beliau akan melakukan pencatatan setiap terjadi transaksi dalam usahanya dan akan melakukan pembukuan sederhana setiap akhir bulannya. Dengan demikian, diharapkan beliau dapat mengetahui berapa keuntungan yang diperoleh dari usahanya dan dapat mengakumulasi pengeluaran dalam setiap produksinya, sehingga beliau dapat memperhitungkan biaya yang harus dikeluarkan dan pendapatan yang bisa diterima setiap bulannya. Selain itu, manfaat lain dari pembukuan sederhana adalah setiap transaksi yang beliau lakukan dalam menjalankan usaha keripik pisang bisa di ketahui dan direkap dengan rinci. Hal tersebut akan memudahkan pendataan terhadap utang dan piutang karena akan terekap dengan baik, jadi hak dan kewajiban dari proses transaksi yang terjadi dapat terpenuhi. Hasil dokumentasi sosialisasi pembukuan sederhana dengan Ibu Masmuah dapat dilihat pada gambar dibawah ini:

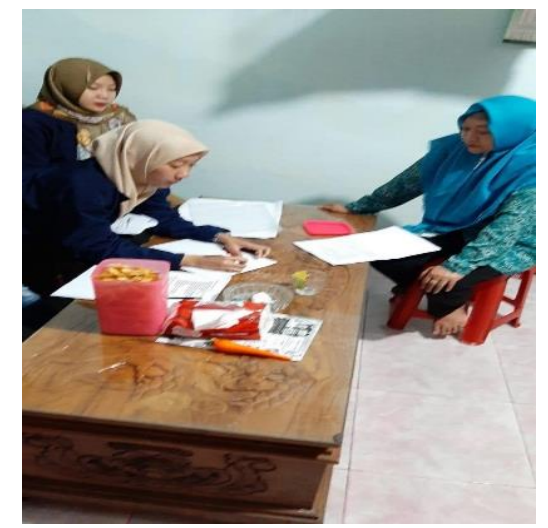

Gambar 3. Sosialisasi pembukuan sederhana dengan Ibu Masmuah

\section{Sosialisasi Packaging Produk atau Kemasan}

Berdasarkan observasi dan wawancara yang telah kami lakukan kepada Ibu Masmuah, sebagai pemilik dari UMKM keripik pisang, menunjukkan bahwa usaha keripik pisang "AQILA" di Desa Bakalan telah memiliki label dan packaging produk atau kemasan yang baik, hanya saja masih terdapat beberapa poin dalam packaging produk yang belum tertulis, antara lain keterangan komposisi produk, keterangan berat neto, dan keterangan tanggal kadaluarsa produk. Oleh karena itu, kami sosialisasikan kembali mengenai pentingnya komposisi, berat neto, dan tanggal kadaluarsa bagi konsumen yang nantinya dapat mempengaruhi penjualan produk. Dari sosialisasi yang telah kami 
lakukan, beliau bersedia untuk mendesain ulang packaging produk atau kemasan dari keripik pisang dengan bantuan dari kami. Desain packaging yang lama dan yang baru dari produk keripik pisang dapat dilihat pada gambar dibawah ini:

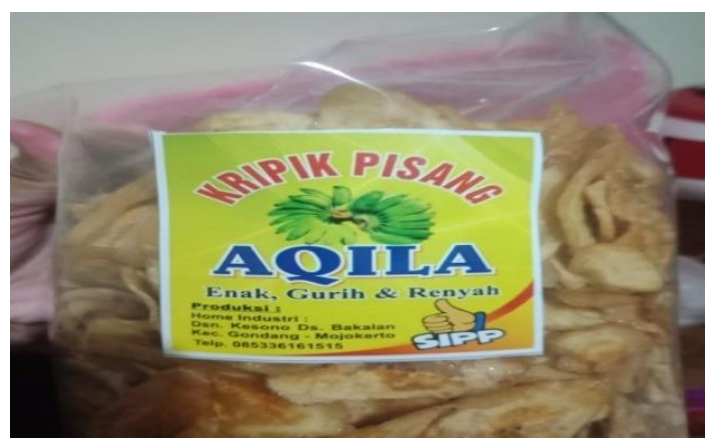

Gambar 4. Desain packaging keripik pisang yang lama
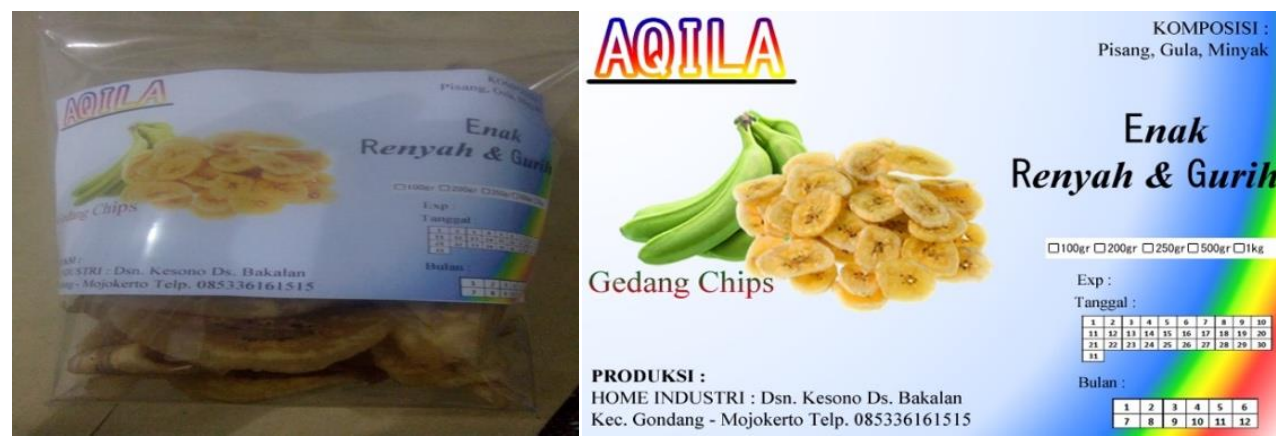

Gambar 5. Desain packaging keripik pisang yang baru

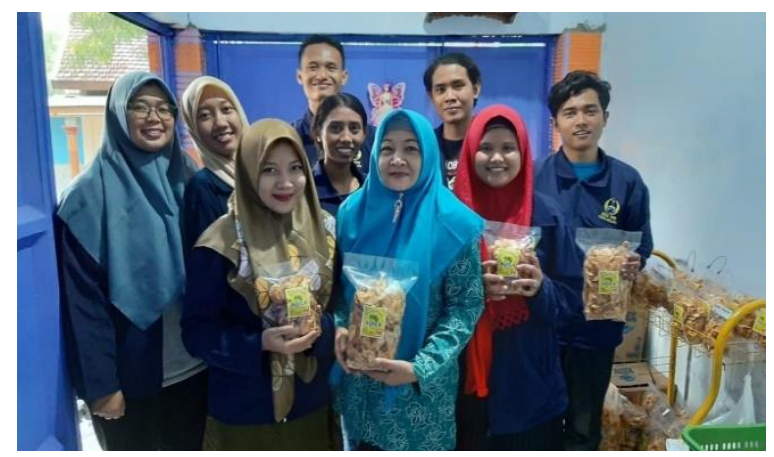

Gambar 6. Sosialisasi packaging keripik pisang dengan Ibu Masmuah

\section{DAMPAK DAN MANFAAT KEGIATAN}

Kegiatan pengabdian masyarakat ini diharapkan dapat meningkatkan pemahaman mengenai SPP-IRT, pembukuan dan packaging pada UMKM, khususnya UMKM keripik pisang "AQILA", sehingga kedepannya dapat meningkatkan penjualan, kualitas, dan pertumbuhan UMKM serta mampu menghadapi persaingan usaha yang ada. 


\section{SIMPULAN}

Pentingnya SPP-IRT, Pembukuan sederhana, dan Packaging (3P) untuk meningkatkan daya saing dan kualitas sangat dibutuhkan oleh UMKM agar bisa bertahan dan terus bersaing ditengah-tengah UMKM yang telah ada maupun UMKM yang baru saja berdiri. Hasil dari pelaksanaan sosialisasi mengenai 3P di UMKM keripik pisang "AQILA" di Desa Bakalan telah terlaksana dengan baik. Hal tersebut dapat diketahui dari hasil yang ada, yaitu pemahaman mengenai SPP-IRT dan minat pemilik usaha keripik pisang "AQILA" untuk segera mengurus SPP-IRT dalam waktu dekat, pemahaman mengenai pembukuan sederhana dan penerapan langsung dihari berikutnya, serta penerapan pemberian saran tambahan unsur komposisi, berat neto, dan tanggal kadaluarsa pada packaging dengan desain baru.

\section{UCAPAN TERIMA KASIH}

Terima kasih kami sampaikan kepada masyarakat Desa Bakalan, terutama kepada para pemilik UMKM, Dinas Kesehatan Kabupaten Mojokerto, Pimpinan Universitas PGRI Adi Buana, serta pihak terkait lainnya yang telah membantu pelaksanaan pengabdian ini agar dapat terlaksana dengan lancar.

\section{DAFTAR PUSTAKA}

Andriawan, F. (2019). Contoh Pembukuan Sederhana untuk Pelaku UMKM. Diakses dari Paper Blog: https://www.paper.id/blog/tips-dan-nasihat-umkm/contohpembukuan-sederhana/.

Ayodya, W. (2018). Bussines Plan: Usaha Kuliner Skala UMKM. Jakarta: Elex Media Komputindo.

Badan Pengawas Obat dan Makanan. 2018. Peraturan Badan Pengawas Obat dan Makanan Nomor 22 Tahun 2018 Tentang Pedoman Pemberian Sertifikat Produksi Pangan Industri Rumah Tangga. Jakarta: Badan Pengawas Obat dan Makanan.

CNN Indonesia. (2019). KEIN Sebut UMKM Kunci Pertumbuhan Ekonomi 7 Persen. Diakses dari CNN Indonesia: https://www.cnnindonesia.com/ekonomi/20190527202520-532-398900/keinsebut-umkm-kunci-pertumbuhan-ekonomi-7-persen.

Desra. (2020). Manfaat Pembukuan bagi Usaha Kecil. Diakses dari Jurnal by Mekari: https://www.jurnal.id/id/blog/manfaat-pembukuan-bagi-usaha-kecil/.

Kementerian Koperasi dan UKM. (2018). Perkembangan Data Usaha Mikro, Kecil, Menengah (UMKM) dan Usaha Besar (UB) Tahun 2017-2018. Jakarta: Kementerian Koperasi dan UKM.

Klimchuk, M. R., \& Krasovec, S. A. (2006). Desain Kemasan: Perencanaan Merk Produk yang Berhasil Mulai dari Konsep sampai Penjualan. Jakarta: Erlangga.

Kotler, P. (1999). Manajemen Pemasaran, Jilid II, Edisi Milenium. Jakarta: Prenhallindo. Pemerintah Republik Indonesia. (2007). Undang-Undang Nomor 28 Tahun 2007 Tentang Ketentuan Umum dan Tata Cara Perpajakan. Jakarta: Pemerintah Republik Indonesia.

Pemerintah Republik Indonesia. (2008). Undang-Undang Nomor 20 Tahun 2008 Tentang Usaha Mikro, Kecil, dan Menengah. Jakarta: Pemerintah Republik Indonesia. 
Rangkuti, F. (2006). Analisis SWOT: Teknik Membedah Kasus Bisnis. Jakarta: Gramedia Pustaka Utama. 